\title{
The origin of high silicon content in potentially medicinal groundwater of Gran Canaria (Canary Islands, Spain). Modelling of chemical water-rock interactions
}

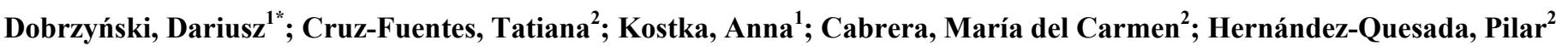 \\ 1 - Department of Groundwater Geochemistry, Faculty of Geology, University of Warsaw, Poland \\ 2 - Department of Physics, University of Las Palmas de Gran Canaria, Spain
}

* corresponding author: d.r.dobrzynski@uw.edu.pl

Key words: silicon-rich water, medicinal water, geochemical modelling, volcanic aquifer, Gran Canaria

Received: 22 November 2012 / Published online: 7 December 2012

\begin{abstract}
Groundwater of Gran Canaria (Canary Island, Spain) have been appreciated and used as an element of health tourism since the 19th Century. This activity was abandoned in the second half of 20th Century when springs disappeared due to groundwater drawdown. The chemistry of groundwater from 19 intakes in volcanic rocks of the north part of Gran Canaria was studied by applying geochemical modelling for quantifying processes responsible for high $\mathrm{Si}$ concentrations.

Studied groundwater has temperature of $16.3^{\circ} \mathrm{C}-25.5^{\circ} \mathrm{C}$, pH of $4.40-7.40$, and usually $\mathrm{HCO}_{3}-(\mathrm{Cl})-\mathrm{Mg}-\mathrm{Ca}-\mathrm{Na}$ hydrochemical types. At near-neutral $\mathrm{pH}$, fresh groundwater usually has $0.1-0.3 \mathrm{mM}$ of $\mathrm{Si}$. In studied groundwater $\mathrm{Si}$ concentrations are 0.42 to $1.82 \mathrm{mM}$, and show positive correlation with ionic strength and temperature. Volcanic bedrocks consist of, generally, easily reactive silicate minerals. Weathering is not supported by low rainfall; however, it shall be intensified by high influx of salts from marine aerosols and lithogenic carbon dioxide into groundwater. Geochemical modelling has found water-mineral reactions which reflect properly diversity of bedrock mineralogy. Based on those chemical reactions, contributions of particular silicate minerals to the pool of silicon dissolved in groundwater were calculated. Understanding the processes responsible for water chemistry might help in proper management and protection of groundwater.

The Si-rich waters might be found in numerous places of Gran Canaria in all volcanic rocks. Silicic acid is the only form of silicon which is biologically available, and is regarded as a component which provides balneotherapeutic benefits. Many studies have showed beneficial and essential aspects of silicon in humans. Studied groundwater from Gran Canaria has an unexploited balneotherapeutic potential, and due to very high Si contents they seem to be ideal for testing the health benefits of such waters to humans. Hydrogeochemical methods, including geochemical modelling, provide effective tools for protection of such medicinal waters.
\end{abstract}

\section{Introduction and aims}

Silicon, the second most abundant of the elements constituting Earth's crust, occurs in groundwater at concentrations are no match numerically for many other elements which are less abundant in the crust. In comparing to rocks, natural waters comparatively are impoverished into silicon. Fresh groundwater usually contains about $0.1 \mathrm{mM} \mathrm{Si}$. The higher Si concentrations, usually up to about $2 \mathrm{mM}$, are found in thermal and/or of extreme-pH groundwater. Silicon content in drinking water is not regulated by standards. At present, this element is regarded as a beneficial, and even an essential for human health (e.g. Exley, 1998, 2009a, 2009b). However, the health benefits of silicon in medicine, also in balneology, were appreciated already in 19th Century (Guibert, 1865; Weber, 1907; Wohlmann, 1914).
Silicon is mentioned as a component which gives therapeutic properties for medicinal waters. In some countries the element is taken into account in balneological regulations, e.g. the threshold value for siliceous curative water was established on $50 \mathrm{mg} / \mathrm{L} \quad(\approx 0.64$ $\mathrm{mM})$ and on $70 \mathrm{mg} / \mathrm{L}(\approx 0.9 \mathrm{mM})$ of $\mathrm{H}_{2} \mathrm{SiO}_{3}$ in Hungary and Poland, respectively.

Groundwater of Gran Canaria (Canary Island, Spain) have been appreciated and used as an element of health tourism since the 19th Century, in localities like Azuaje, Berrazales, Teror and Telde. This activity was abandoned in the second half of 20th Century (e.g. Jiménez et al., 2012; Rodríguez et al., 2012), when springs disappeared due to the generalized groundwater levels drawdown in the island. At present, chemically valuable groundwater from several localities of Gran Canaria from exploited wells are used for 
production of bottled water only.

Volcanic history and geological setting of Gran Canaria are predestining their groundwater for being enriched into some compounds, like carbon dioxide, silica or fluorine. The presented study has focused on the composition of groundwater in northern part of Gran Canaria at places where increased $\mathrm{Si}$ content has been documented. Studied groundwater has high contents of dissolved silicon, often higher than in many balneologically-used medicinal waters of European spas.

Geochemical modelling has been applied with the aim of elucidating and quantifying the main chemical reactions responsible for high silicon concentration in groundwater of northern Gran Canaria. The balneological potential of studied groundwater is underrated. Understanding the processes responsible for water chemistry might help in proper management and protection of groundwater.

\section{Materials and methods}

Studied groundwater occurs in volcanic rocks divided to three main volcanic suites: Miocene Phonolites, Pliocene Roque Nublo Group including mafic lavas and breccia type ignimbrites deposits with juveniles of phonolitic composition (Mangas et al., 1993), and Quaternary Post Roque Nublo basalts and basanites. Groundwater from 19 largediameter $(2.5$ and $3 \mathrm{~m}$ ) wells was sampled and analysed (Fig. 1). In water samples physicochemical parameters $(\mathrm{pH}, \mathrm{T}, \mathrm{SEC})$ were determined in the field and dissolved constituents were determined in the labs.

A multivariate statistical cluster analysis technique was applied to groundwater data. The data were subjected to Q-mode hierarchical and to k-means cluster analyses by using STATISTICA program (StatSoft, 2005) for classifying the groundwater samples into hydrochemical groups, and for selecting representative water wells for geochemical modelling. The Ward's linkage method was applied, and Manhattan distance was chosen as a measure of similarity.

The main geochemical reactions responsible for groundwater chemistry have been defined and quantified by applying geochemical inverse mass balance modelling by using
PHREEQC program (Parkhurst and Appelo, 1999) with llnl thermodynamic database. For geochemical modelling four water wells (nos. 3, 9, 17, 18 - Fig. 1) were selected, representing almost homogeneous type of bedrocks. Wells 3 and 9 show groundwater which flows mainly through Miocene trachyte-phonolites; well 18 - water through rocks of Roque Nublo group, and well 17 through Post Roque Nublo rocks.

Outlines of conceptual geochemical model are presented on Figure 2. At first step, the pure water was equilibrated with respect to atmospheric $\mathrm{CO}_{2}$ and evaporated for imitating clean rain water chemistry (input water in the model). Evapotranspiration coefficients and mean air temperatures at recharge zone of each well were applied (Cruz et al., 2012). Next, inverse mass balance modelling was done between input water (recharging water), defined in such a way, and groundwater from particular wells (output water). Three main kinds of source phases which might release substances into solution have been included in the conceptual model: marine aerosols, minerals of volcanic bedrocks, and $\mathrm{CO}_{2}$ of volcanic origin (Fig. 2). Marine aerosols were assumed to be of mean composition $\mathrm{Na}_{0.779} \mathrm{Mg}_{0.0875} \mathrm{Ca}_{0.0145} \mathrm{~K}_{0.017} \mathrm{Cl}_{0.906}\left(\mathrm{SO}_{4}\right)_{0.047}$ based on the mean sea water chemistry. Minerals included in models cover primary minerals (mainly silicates) and secondary clay minerals. There have been selected minerals which were documented by petrologic studies and present chemistry the closest to genuine minerals.

\section{Geological setting and hydrogeology}

The study area, located in the northern part of Gran Canaria (Canary Island, Spain) (Fig. 1), is shaped by a series of radial gullies formed in the centre of island (at max. 1949 m a.s.l.), which run into the sea. The climate of Gran Canaria is subtropical. Average annual rainfall is $375 \mathrm{~mm} / \mathrm{y}$, varying between 820 $\mathrm{mm} / \mathrm{y}$ in the highlands and $115 \mathrm{~mm} / \mathrm{y}$ on the coast. The air temperature is moderate. Average annual temperature varies from $12^{\circ} \mathrm{C}$ in the highlands to $22^{\circ} \mathrm{C}$ at the coast, with an average temperature of $18^{\circ} \mathrm{C}$.

The geology of the study area shows volcanic and sedimentary materials (Fig. 1). On the surface, basaltic, basanitic and trachybasaltic 
lavas of the Roque Nublo and Post-Roque Nublo suites, and sediments of Las Palmas detritic Formation mainly occur. Miocene trachytic and phonolitic lavas outcrop usually in the coastal area and at the bottom of ravines, where alluvial deposits are also observed (Aulinas et al., 2010; Perez-Torrado et al., 1995). Volcanic rocks mostly consist of diopside, olivine and labradorite (mainly in basaltic, basanitic and trachybasaltic lavas), and andesine, kaersutite, anorthoclase and hauyne in Miocene trachyte-phonolite rocks (Perez-Torrado, 1992; Aulinas et al., 2010). Sediments, weathering cover, and fillings of fractures also include calcite, dolomite, gypsum and clays (illite, and smectites, usually montmorillonites), and zeolites (analcime, chabazite, phillipsite).

The island aquifer is conceptualised as a stratified and heterogeneous water-body, with groundwater flows from recharge area (at the summits in the central part of island) towards the coast. There are hydraulic connections between waters occurring in different rocks, which actually form one common hydrogeological system in the island (SPA15, 1975; Custodio and Cabrera, 2008). In the study area, groundwater comes predominantly from Roque Nublo group rocks and underlying Miocene trachytic and phonolitic lavas. Groundwater exceptionally flows towards the deep gullies ("barrancos") and generally discharges to the coast located at the north (Fig. 1). An important amount of groundwater is also discharged artificially due to withdrawals from wells and galleries. Agriculture, which is mainly practised on the coastal areas, is supplied from both surface and ground water resources, and locally causes an important irrigation return flows (Cabrera and Custodio, 2004; Custodio and Cabrera, 2008), which promote increase of soil and groundwater salinity.

\section{Silicon in studied groundwater}

Studied groundwater are low-mineralized with specific electric conductivity (SEC) ranging between 280 and $2760 \mu \mathrm{S} / \mathrm{cm}$, and mostly weakly acid, with $\mathrm{pH}$ varying from 4.40 to 7.40 (Tab. 1). Bicarbonate waters of $\mathrm{HCO}_{3}-\mathrm{Mg}-\mathrm{Ca}-\mathrm{Na}$ hydrochemical types prevail (Fig. 3). Main parameters of groundwater chemistry were summarized in
Table 1.

Silicon in fresh groundwater of near-neutral $\mathrm{pH}$, also those which occur in volcanic rocks, usually shows concentrations of $0.1-0.3 \mathrm{mM}$ (Dobrzyński, 2006, 2007). In studied groundwater $\mathrm{Si}$ concentrations are clearly higher, and vary from 0.42 to $1.82 \mathrm{mM}$ (mean $1.28 \mathrm{mM})$. Dissolved silicon presents correlation with ionic strength of solution (Fig. 4), and noticeable chemical diversity. Groups of wells distinguished on Figure 4 apparently refer to hydrogeological and hydrogeochemical conditions. It might be assumed that revealed diversity mainly is being triggered through: (1) reactivity of volcanic bedrocks, and (2) local hydrogeological and anthropogenic factors.

Groundwater sub-populations indentified on Figure 4 are caused by above mentioned factors. Groundwater of group I (wells nos. 1, $5,6,11,13,17,19)$ contacts with rocks of Post Roque Nublo and Roque Nublo groups. Waters of wells nos. 2, 3, 8, 9, 10, 12, 14, 15, 16 occur mainly in Phonolites and Roque Nublo rocks, and might be divided into two groups (Fig. 4): "IIa" and "IIb". Waters of IIb-group have lower mineralization, and occur at higher altitudes than waters of IIagroup. Water from well 18 shows an intermediate chemistry mainly formed due to contact with Roque Nublo rocks. Groundwater from wells 4 and 7 (group III) demonstrate mineralization higher than other waters, what results from irrigation activity and/or sea water intrusion. A pattern of groundwater subpopulations very similar to that showed on Figure 4 has been also recognized by means of both hierarchical (Fig. 5) and k-means (Tab. 2) cluster analysis. In most groundwater, silicon occurs as (ortho)silicic acid $\left(\mathrm{H}_{4} \mathrm{SiO}_{4}\right)$, and it's concentration is chiefly governed by temperature and $\mathrm{pH}$. Also in studied groundwater, the higher temperature, the higher Si concentration (Fig. 6A). The Sitemperature pattern is only "disturbed" by salinity-affected waters (wells 4 and 7), which show relatively high temperatures.

In studied groundwater, with $\mathrm{pH}$ between 4.40 and 7.40, silicic acid remains undissociated. Increase of $\mathrm{Si}$ concentrations at this $\mathrm{pH}$ range depends on factors other than dissociation, like temperature, bedrock 
reactivity, water chemistry (aggressiveness), water residence time. Waters of wells 2, 10, 16 (IIb group on Figure 4), which occur at the highest altitudes, and represent shorter water residence times, have the lowest $\mathrm{Si}$ concentrations (11.8-23.1 mg/L Si) (Fig. 6B, Tab. 1). Salinity-affected waters (wells 4 and 7) and waters from wells 6, 12 and 15 have, at $\mathrm{pH}$ of 6.0-6.7, slightly higher $\mathrm{Si}$ concentrations $(27.7-34.6 \mathrm{mg} / \mathrm{L} \quad \mathrm{Si})$ than waters of the IIb group. Remaining waters have lower $\mathrm{pH}$ (4.40-6.20), what probably results from still un-neutralised pool of $\mathrm{CO}_{2}$, and contain higher $\mathrm{Si}$ concentrations (35.3$51.0 \mathrm{mg} / \mathrm{L} \mathrm{Si}$ ). Concentrations of dissolved silicon in studied groundwater are high and close to the solubility limit of silicic acid (1.942 mM), at $25^{\circ} \mathrm{C}$ (Fig. 4).

At chemical equilibrium in the groundwaterrock system, Si concentrations are controlled by solubility of minerals. However, in aquifers of so-called active zone, like in the case of studied fissured volcanic aquifers, non- or meta-stable equilibrium usually occur, and $\mathrm{Si}$ concentration meets a quasi steadystate conditions. Generally, the chemical composition of groundwater, including silicon concentration, in particular points of the geochemical system depends on steady-state conditions between three main groups of processes: (1) releasing substances into a solution from decaying/transforming minerals, (2) immobilizing substances in a newly formed secondary solids (colloids, minerals), and (3) removing solutes together with ground and surface waters running off. About $90 \%$ of the continental crust is built of silicate minerals, which create a vast reservoir of source mineral phases releasing $\mathrm{Si}$ into natural waters. However, resistance to weathering and usually low solubility of silicate minerals significantly limit $\mathrm{Si}$ concentration in waters.

The influx of lithogenic (volcanic) $\mathrm{CO}_{2}$ into groundwater of Gran Canaria increases their aggressiveness with respect to bedrocks. Results show that $\mathrm{CO}_{2}$ influx, at first, destabilises the chemical equilibrium, and responds for rapid increase of both dissolved inorganic carbon (DIC) and Si concentrations, until finally the partial chemical equilibrium with some minerals is probably reached and Si content quasi-stabilized at level of about
$1.4 \mathrm{mM}$ (Fig. 6C). Achieving the chemical equilibrium with secondary, neo-formed minerals, mainly clay minerals, favours stabilization of silicon concentrations.

\section{Geochemical modelling}

Inverse geochemical modelling provided data on reactions which are responsible for the water chemistry in Post Roque Nublo, Roque Nublo, and Phonolites aquifer-rocks. Representative groundwater selected for geochemical modelling (wells - nos. 3, 9, 17, 18) contact with most homogeneous bedrock and present chemical composition least changed by the human activity. In lithological profiles of wells 3 and 9 phonolite rocks dominate. In the profile of well 17 Post Roque Nublo rocks are only present, while in profile of well 18 Roque Nublo rocks prevail.

Several models have been found for groundwater from each particular wells. Three models have been found for water from well no. 3, six models for well no. 9, and four models both for waters from wells nos. 17 and 18. Models recognized phases which deliver substances into a solution (source phases) and phases which immobilize solutes from water (so-called sink phases), and quantified amount of each (dissolved or precipitated) phases by giving a mole transfer (in $\mathrm{mol} / \mathrm{kg}$ $\mathrm{H}_{2} \mathrm{O}$ ).

Because the models which have been found for groundwater from each aquifer-rock types presented considerable resemblances, their results are expressed in a synthetic way (Tab. 3). Phases which have been included in every model play an essential role in the forming of groundwater chemistry. Reactions with mineral phases which occurred optionally in models might be displaced by reactions with some other minerals while water-rock interactions in the natural systems.

In all aquifer-rock types, important effects of both lithogenic $\mathrm{CO}_{2}$ and marine aerosols were confirmed. The mean influx of $\mathrm{CO}_{2}$ and marine aerosols ranges from 15.5 to 50.8 $\mathrm{mmol} / \mathrm{L}$, and from 0.52 to $3.39 \mathrm{mmol} / \mathrm{L}$, respectively (Tab. 3). The dissolved $\mathrm{CO}_{2}$ presents the highest mole transfers amongst phases included in models.

Apart from $\mathrm{CO}_{2}$ and marine aerosols, primary and secondary minerals have been considered in found models. Reactions with those 
minerals depend on bedrock mineralogy. In all aquifer rocks the main source mineral phases are various feldspars and diopside (pyroxene). In Roque Nublo and Phonolites also feldspathoides (hauyne, nepheline) and biotites play the role, while in Post Roque Nublo - olivines. The secondary silicates considered in all models are montmorillonites of various chemical compositions. Mole transfers for silicate minerals are usually of 0.01 to $1 \mathrm{mmol} / \mathrm{L}$ (Tab. 3 ).

Modelling results were used for the quantitative description of the contribution of particular minerals to amount of dissolved silicon. Contributions are expressed in the percentage of total Si released into solutions (Tab. 4). In all aquifer rocks, acid plagioclase end-member, albite (avg. 30-49 \%) and diopside (avg. 19-42\%) contribute the most of silicon. The anorthite contribution varies between $1.5 \%$ and $10.3 \%$. Potassium feldspars play the role only in Post Roque Rock bedrock, contributing about $13 \%$ of Si. Apart from feldspars and diopside, in Phonolite and Roque Nublo bedrocks feldspathoides (avg. 13.7-15.3\%) and biotites (11.2-18.8\%) play secondary role, while in Post Roque Rock olivines contribute $5.5 \%$ of dissolved $\mathrm{Si}$ on average. Contributions from kaersutite and titanite are negligible.

\section{Conclusions}

In the north of Gran Canaria, Si-rich groundwater might be found in rocks of all volcanic complexes. Obtained data shall be useful in hydrogeochemical forecasting of the groundwater quality. Understanding the processes which form chemistry of groundwater is important from both pure and applied view-points, because it helps us to protect quantity and quality of groundwater resources, like valuable medicinal waters. The performed geochemical modelling provides information about the total effect of waterrock interactions, irrespectively of the residence time of water in bedrocks. The longer time of water-rock contact usually supports increase of solutes concentration. Obtaining quantitative information about the intensity of particular chemical reactions in individual parts of the studied area would require further studies, e.g. on environmental tracers in groundwater.
Young volcanic bedrocks in studied area consist of, generally, easily reactive minerals. Weathering is not supported by low rainfall, however, it shall be intensified by dissolving of salts from marine aerosols and lithogenic carbon dioxide in groundwater. Diversity of bedrock mineralogy is well reflected by found water-mineral reactions. The common features of all volcanic aquifer-bedrocks are decaying of feldspars and pyroxenes, and formation of smectites.

Silicic acid is the only form of silicon which is biologically available. In some countries, silicon (silicic acid) is regarded as a beneficial component which provides balneotherapeutic benefits. Many studies have showed beneficial and essential aspects of silicon in humans, e.g. because it limits bioavailablity of toxic aluminium, and detoxifies organisms. Silicic acid at concentration greater than 0.5 $\mathrm{mM}$ in drinking waters has been suggested that show some protection against Alzheimer's disease (Exley et al., 2006). Bioavailable silicon is depleted from the most of products in our diet; also waters we drink usually have very low Si concentration of about $0.1 \mathrm{mM}$. Naturally Si-rich (fresh and medicinal) groundwater are used only locally. Unfortunately, therapeutic potential of Si-rich waters is still underrated (Dobrzyński and Exley, 2010).

The potential Si-rich therapeutic water might be found in numerous places of the northern part of Gran Canaria island. While planning to use these waters it is necessary to consider hydrogeological and environment pollution issues. An earlier identification and an assessment of hydrogeological and hydrogeochemical conditions are required. Hydrogeological and hydrogeochemical methods, including geochemical modelling, provide effective tools for protection of medicinal waters.

Studied groundwater from the north part of Gran Canaria have very high Si contents, higher than in many balneologically-used medicinal waters of Europe, and an unexploited balneotherapeutic potential. The studied waters have silicic acid concentration much higher than above mentioned $0.5 \mathrm{mM}$ level, and they seem to be ideal for testing the health benefits of such waters to humans. 


\section{Acknowledgements}

Studies of groundwater chemistry have been realized partly in frames of the project realized at the Faculty of Geology, University of Warsaw, Poland (grant no. N307103435), and partly by the projects CONSOLIDERTRAGUA (CSD2006-00044) and REDESAC (CGL2009-592 12910-C03-02), realized at the GEOVOL Group (University of Las Palmas de Gran Canaria, Spain).

\section{References}

Aulinas M., Gimeno D., Fernández-Turiel J.L., Pérez-Torrado F.J., RodríguezGonzález A. and Gasperini D., 2010. The Plio-Quaternary magmatic feeding system beneath Gran Canaria (Canary Islands, Spain): Constraints from thermobarometric studies. Journal of the Geological Society of London, 167, 785-801.

Balcells et al., 1990. Proyecto MAGNA. Memorias y mapas geológicos de España a escala 1:25 000. Isla de Gran Canaria: hojas $n^{0}$ 1101-I-II-III-IV, 1109-I_IV. IGME.

Benavides A. and Galindo E., 2011. Estudio de la evolución de la superficie piezométrica de la zona norte de la isla de Gran Canaria. In: Cabrera M.C, Jiménez J., Custodio E., (eds.): El conocimiento de los recursos hídricos en Canarias cuatro décadas después del Proyecto SPA-15 (Digital book). Ed. IAH- Spanish group. Las Palmas de Gran Canaria.

Cabrera M.C. and Custodio E., 2004. Groundwater flow in a volcanicsedimentary coastal aquifer: Telde area, Gran Canaria, Canary Islands, Spain. Hydrogeology Journal, 12, 305-320.

Cruz T., Benavides A., Narano G., Cabrera M.C., Hernández P., Estévez E., Martín L.F. and Custodio E., 2012. Estimación de la recarga natural media en la zona noreste de Gran Canaria (Islas Canarias, España) mediante el balance de cloruros atmosféricos. In: Lambán J.L., Carceller T., Valverde M. and Fernández-Jaúregui C. (eds.). Las aguas subterráneas: desafíos de la gestión para el siglo XXI. (Digital book). Ed. IAH- Spanish Group.

Custodio E. and Cabrera M.C., 2008. Synthesis of the Canary Islands hydrogeology. In: International
Symposium in Hydrogeology -

Hydrogeology of volcanic rocks, SIHD2008 Abstracts book, Djibouti, 51-56.

Dobrzyński D., 2006. Silica solubility in groundwater from Permian volcanogenic rocks (the Sudetes Mts., SW Poland) - the role of reversible aluminosilicate solids. Geological Quarterly, 50, 407-417.

Dobrzyński D., 2007. Chemistry of neutral and alkaline waters with low $\mathrm{Al}^{3+}$ activity against hydroxyaluminosilicate $\mathrm{HAS}_{\mathrm{B}}$ solubility. The evidence from ground and surface waters of the Sudetes Mts. (SW Poland). Aquatic Geochemistry, 13, 197210.

Dobrzyński D. and Exley C., 2010. Solubility control and therapeutic potential of silicon in curative mineral waters of the Sudetes Mountains, Poland. Acta Balneologica, 52(4), 296-304.

Exley C., 1998. Silicon in life: A bioinorganic solution to bioorganic essentiality. Journal of Inorganic Biochemistry, 69, 139-144.

Exley C., 2009a. Darwin, natural selection and the biological essentiality of aluminium and silicon. Trends in Biochemical Sciences, 34, 589-593.

Exley C., 2009b. Silicon in Life: Whither Biological Silicifcation? In: Müller W.E.G. and Grachev M.A. (eds.) Biosilica in Evolution, Morphogenesis, and Nanobiotechnology. Progress in Molecular and Subcellular Biology, Marine Molecular Biotechnology, 47, 173-184.

Exley C., Korchazhkina O., Job D., Strekopytov S., Polwart A. and Crome P., 2006. Non-invasive therapy to reduce the body burden of aluminium in Alzheimer's disease. Journal of Alzheimer's Disease, $10,17-24$.

Guibert V., 1865. Histoire naturelle et médicale des noveaux médicaments introduits dans la thérapeutique depuis 1830 jusqu'a nos jours. Bruxelles, $681 \mathrm{p}$.

Jiménez J.F., Rodríguez B.C., Navarro E., Jiménez C., Camacho C. and Jiménez Y., 2012. Historiography of acidulous waters in the Canary Islands. Anales de Hidrología Médica, series Balnea, 6, 440441.

Mangas J., Pérez-Torrado F.J., Massare D. and Clocchiatti R., 1993. Phonolitic origin of Roque Nublo ignimbrites of Gran 
Canaria (Canary Islands, Spain) from clinopyroxene melt inclusion studies. European Journal of Mineralogy, 5, 97106.

Parkhurst D.L. and Appelo C.A.J., 1999. User's guide to PHREEQC (version 2) - A computer model for speciation, batchreaction, one-dimensional transport, and inverse geochemical calculations. U.S. Geological Survey, WRI Report, 99-4259, $1-326$.

Perez-Torrado $\quad$ F.J., 1992. Volcanoestratigrafía del grupo Roque Nublo (Gran Canaria). Departamento de Física. Universidad de Las Palmas de Gran Canaria, Las Palmas de Gran Canaria. 459 p.

Pérez-Torrado F.J., Carracedo J.C. and Mangas J., 1995. Geochronology and stratigraphy of the Roque Nublo Cycle, Gran Canaria, Canary Islands. Journal of the Geological Society of London, 152,
807-818.

Rodríguez B.C., Jiménez J.F., Navarro E., Jiménez Y., Camacho C., and Jiménez C., 2012. Splendour and decadence of spa tourism in the island of Gran Canaria. Anales de Hidrología Médica, series Balnea, 6, 444-445.

SPA-15, 1975. Estudio científico de los recursos de agua en las Islas Canarias [Scientific study of the water resources in Canary Islands], Project SPA/69/515 MOP (DGOH)-PNUD (UNESCO). Dirección General de Obras Hidráulicas-UNESCO, Madrid, 4 vols.

StatSoft, Inc., 2005. STATISTICA (data analysis software system), version 7.1. (www.statsoft.com)

Weber H., 1907. Climatotherapy and balneotherapy. London, $833 \mathrm{p}$.

Wohlmann A.S., 1914. The mineral waters and spas of New Zealand. Wellington, $155 \mathrm{p}$. 


\section{List of Tables and Figures}

Table 1. Main physicochemical parameters of studied groundwater. Concentrations in $\mathrm{mg} / \mathrm{L}$, except $\mathrm{Al}$ given in $\mu \mathrm{g} / \mathrm{L}$.

Table 2. Clusters and their members in Q-mode, k-means clustering analysis of studied groundwater.

Table 3. The mean mole transfer (in $\mathrm{mol} / \mathrm{kg}$ of $\mathrm{H}_{2} \mathrm{O}$ ) of phases responsible for formation of groundwater chemistry in volcanic bedrocks (based on results of inverse mass balance geochemical modelling).

Table 4. The weathering contribution (in \%) of silicate source mineral phases to the pool of silicon dissolved in studied groundwater. Mean values are given in brackets.

Figure 1. Localization, geologic map (after Balcells et al., 1990, modified) and groundwater head contours map (Benavides and Galindo, 2011) for 2008 of study area in the northern part of Gran Canaria. Explanations: 1-19 - numbers of sampled water wells.

Figure 2. Scheme of conceptual geochemical model for water-rock interactions in Gran Canaria island.

Figure 3. Stiff diagrams map reflecting groundwater chemistry of sampled wells.

Figure 4. Silicon concentration versus ionic strength of groundwater. Explanations: 1-19 - numbers of sampled wells. Groups of wells: I - groundwater chemistry dominated by interactions with Post Roque Nublo and Roque Nublo volcanic rocks; IIa, IIb - groundwater chemistry dominated by interactions with Phonolites and Roque Nublo volcanic rocks; III - groundwater chemistry affected by irrigation and/or sea salinity. Green line - minimum threshold value of Si content $(0.5 \mathrm{mM})$ suggested as a beneficial for human health (after Exley et al., 2006); red line - solubility limit of silicic acid $(1.94 \mathrm{mM})$, at $25^{\circ} \mathrm{C}$; dark blue lines - ranges of silicon content typical for fresh groundwater. Groundwater used in inverse geochemical modelling (wells nos. 3, 9, 17, and 18) are marked as red filled circles.

Figure 5. Hierarchical Q-mode cluster dendrograms of studied groundwater based on: 5A - major solutes chemistry data; 5B - major and minor chemistry data, water table data, and contribution of bedrocks in alimentation zone. 1-19 - numbers of sampled wells. Dashed lines added for highlighting groups of clustered water members.

Figure 6. Silicon concentration versus temperature (6A), $\mathrm{pH}(6 \mathrm{~B})$, and dissolved inorganic carbon (6C) in groundwater. 1-19 - numbers of sampled wells. 
Table 1. Main physicochemical parameters of studied groundwater. Concentrations in $\mathrm{mg} / \mathrm{L}$, except $\mathrm{Al}$ given in $\mu \mathrm{g} / \mathrm{L}$.

\begin{tabular}{|c|c|c|c|c|c|c|c|c|c|c|c|c|c|c|c|c|}
\hline Well & Number & Name & $\begin{array}{l}\mathrm{T} \\
{\left[{ }^{\circ} \mathrm{C}\right]}\end{array}$ & $\begin{array}{l}\mathrm{SEC}^{1} \\
{[\mu \mathrm{S} / \mathrm{cm}]}\end{array}$ & $\mathrm{pH}$ & $\mathrm{Si}$ & $\mathrm{Al}$ & $\mathrm{HCO}_{3}$ & $\mathrm{Cl}$ & $\mathrm{SO}_{4}$ & $\begin{array}{l}\mathrm{NO} \\
3 \\
\end{array}$ & $\mathrm{~F}$ & $\mathrm{Ca}$ & $\mathrm{Mg}$ & $\mathrm{Na}$ & K \\
\hline 1 & 0007-NA & $\begin{array}{l}\text { Fuente } \\
\text { Agria }\end{array}$ & 21.0 & 468 & 5.00 & 35.275 & 47 & 134.2 & 83 & 27 & 33 & 0.47 & 17.37 & 16.52 & 45.1 & 7.2 \\
\hline 2 & 0267-CP & Pozo Chico & 16.3 & 692 & 7.40 & 11.804 & $<1$ & 68.0 & 66 & 83 & 152 & 0.31 & 31.71 & 24.11 & 44.16 & 13.88 \\
\hline 3 & 0316-CP & $\begin{array}{l}\text { La } \\
\text { Parralilla }\end{array}$ & 20.0 & 1170 & 5.60 & 43.043 & 4 & 573.6 & 108 & 43 & 14 & 0.26 & 57.99 & 44.04 & 96.45 & 13.74 \\
\hline 4 & 0410-ТP & $\begin{array}{l}\text { La } \\
\text { Marciega }\end{array}$ & 25.5 & 2760 & 6.29 & 30.342 & 2 & 939.7 & 388 & 134 & 53 & 0.97 & 78.57 & 73.48 & 272.95 & 14.87 \\
\hline 5 & 0586-ТP & $\begin{array}{l}\text { Finca } \\
\text { Rapador }\end{array}$ & 19.0 & 463 & 5.85 & 47.153 & 3 & 231.9 & 32 & 18 & 37 & 0.21 & 36.39 & 21.63 & 27.75 & 6.85 \\
\hline 6 & 0755-TP & Barreto & 18.8 & 280 & 6.70 & 31.786 & $<1$ & 146.4 & 41 & 11 & 11 & 0.25 & 13.16 & 14.58 & 42.85 & 4.95 \\
\hline 7 & 0946-ТP & $\begin{array}{l}\text { Hoya del } \\
\text { Cano }\end{array}$ & 23.0 & 2680 & 6.31 & 27.680 & $<1$ & 671.2 & 304 & 266 & 169 & 1.19 & 22.5 & 35.71 & 416.18 & 19.88 \\
\hline 8 & 1083-TP & $\begin{array}{ll}\text { Cueva } & \text { de } \\
\text { Matos } & \\
\end{array}$ & 20.0 & 1200 & 6.14 & 48.100 & 7 & 781.0 & 52 & 32 & 1.2 & 0.27 & 94.62 & 52.91 & 62.57 & 13.41 \\
\hline 9 & 1254-TP & $\begin{array}{l}\text { Cuesta La } \\
\text { Arena }\end{array}$ & 22.5 & 1156 & 5.62 & 38.760 & $<1$ & 659.0 & 66 & 18 & 11 & 0.24 & 48.11 & 53.31 & 91.07 & 9.8 \\
\hline 10 & 1277-TP & El Laurel & 17.7 & 700 & 5.80 & 21.379 & $<1$ & 231.9 & 52 & 55 & 105 & 0.34 & 40.39 & 28.82 & 41.87 & 11.35 \\
\hline 11 & 1485-TP & Las Pellas & 20.0 & 490 & 5.30 & 36.827 & 35 & 292.9 & 35 & 6.3 & 9.4 & 0.2 & 27.45 & 23.3 & 37.76 & 5.53 \\
\hline 12 & 1993-ТP & $\begin{array}{l}\text { Los } \\
\text { Lomitos }\end{array}$ & 20.0 & 965 & 6.52 & 34.627 & $<1$ & 305.1 & 97 & 87 & 35 & 0.36 & 50.92 & 40.91 & 73.69 & 7.83 \\
\hline 13 & 78-TP & El Rapador & 21.5 & 617 & 6.15 & 51.013 & 22 & 353.9 & 29 & 7 & 17 & 0.24 & 48.18 & 29.98 & 37.28 & 8.36 \\
\hline 14 & 2250-TP & San Anton & 21.0 & 1145 & 6.08 & 46.380 & 4 & 671.2 & 59 & 39 & 3.1 & 0.43 & 91.1 & 47.15 & 60.23 & 11.13 \\
\hline 15 & 2558-TP & $\begin{array}{l}\text { Hoya del } \\
\text { Pedregal }\end{array}$ & 20.0 & 832 & 6.01 & 32.937 & 3 & 549.2 & 39 & 24 & 23 & 0.35 & 66.68 & 40.21 & 45 & 8.69 \\
\hline 16 & 2730-ТP & $\begin{array}{l}\text { Finca Los } \\
\text { Palos }\end{array}$ & 19.3 & 678 & 7.00 & 23.153 & $<1$ & 402.7 & 39 & 45 & 17 & 0.84 & 34.88 & 32.68 & 47.51 & 9.95 \\
\hline 17 & 3309-TP & Cazadores & 21.0 & 469 & 5.77 & 40.819 & $<1$ & 317.3 & 20 & 2.5 & 0.5 & 0.27 & 36.16 & 21.97 & 27.95 & 6.33 \\
\hline 18 & 3968-TP & $\begin{array}{l}\text { Caidero del } \\
\text { Lance }\end{array}$ & 20.0 & 869 & 6.21 & 43.936 & 4 & 549.2 & 47 & 31 & 3.9 & 0.23 & 62.37 & 37.39 & 52.66 & 9.07 \\
\hline 19 & 6138-ТP & $\begin{array}{ll}\text { Finca } & \text { La } \\
\text { Palma } & \end{array}$ & 19.9 & 303 & 4.40 & 35.983 & 31 & 109.8 & 55 & 14 & 17 & 0.8 & 9.32 & 8.16 & 37.52 & 4.96 \\
\hline
\end{tabular}

1 - SEC - specific electric conductivity 
Table 2. Clusters and their members in Q-mode, k-means clustering analysis of studied groundwater.

\begin{tabular}{|c|c|c|c|}
\hline $\begin{array}{l}\text { Aggregat } \\
\text { ions }\end{array}$ & \multirow[b]{2}{*}{ II } & \multirow[b]{2}{*}{ III } & \multirow[b]{2}{*}{ IIV } \\
\hline I & & & \\
\hline \multicolumn{4}{|l|}{$\begin{array}{l}\text { Water } \\
\text { wells }\end{array}$} \\
\hline 1 & 2 & 3 & 4 \\
\hline 5 & 10 & 8 & 7 \\
\hline 6 & 16 & 9 & \\
\hline 11 & & 12 & \\
\hline 17 & & 13 & \\
\hline \multirow[t]{3}{*}{19} & & 14 & \\
\hline & & 15 & \\
\hline & & 18 & \\
\hline
\end{tabular}


Table 3. The mean mole transfer (in $\mathrm{mol} / \mathrm{kg}$ of $\mathrm{H}_{2} \mathrm{O}$ ) of phases responsible for formation of groundwater chemistry in volcanic bedrocks (based on results of inverse mass balance geochemical modelling).

\begin{tabular}{|c|c|c|c|c|c|c|}
\hline \multirow{2}{*}{ Phase } & \multirow{2}{*}{ Formula } & & \begin{tabular}{|l|} 
Post Roque \\
Nublo \\
\end{tabular} & $\begin{array}{l}\text { Roque } \\
\text { Nublo } \\
\end{array}$ & $\begin{array}{l}\text { Phon } \\
\text { olites }\end{array}$ & \\
\hline & & & \begin{tabular}{|ll} 
Well & 17 \\
$(4)^{1}$ & \\
\end{tabular} & \begin{tabular}{|ll}
$\begin{array}{l}\text { Well } \\
(4)^{1}\end{array}$ & 18 \\
\end{tabular} & $\begin{array}{ll}\text { Well } & 3 \\
(3)^{1} & \end{array}$ & Well $9(6)^{1}$ \\
\hline Lithogenic $\mathrm{CO}_{2(\mathrm{~g})}$ & & \multirow{16}{*}{$\begin{array}{l}\text { Source } \\
\text { phases }\end{array}$} & $2.108 E-02$ & $1.553 E-02$ & \begin{tabular}{|l}
$4.374 \mathrm{E}-$ \\
02 \\
\end{tabular} & $5.081 \mathrm{E}-02$ \\
\hline Marine aerosols ${ }^{2}$ & $\begin{array}{l}\mathrm{Na}_{0.779} \mathrm{Mg}_{0.0875} \mathrm{Ca}_{0.0145} \mathrm{~K}_{0.017} \mathrm{Cl}_{0.906}(\mathrm{~S} \\
\left.\mathrm{O}_{4}\right)_{0.047}\end{array}$ & & 5.171E-04 & $1.465 E-03$ & \begin{tabular}{|l|}
$3.386 E-$ \\
03 \\
\end{tabular} & 2.057E-03 \\
\hline $\begin{array}{l}\text { Potassium } \\
\text { Feldspar }\end{array}$ & $\mathrm{KAlSi}_{3} \mathrm{O}_{8}$ & & $2.502 E-04$ & & & \\
\hline Albite & $\mathrm{NaAlSi}_{3} \mathrm{O}_{8}$ & & 9.105E-04 & $5.783 E-04$ & $\begin{array}{l}\text { 8.729E- } \\
04\end{array}$ & $1.670 \mathrm{E}-03$ \\
\hline Anorthite & $\mathrm{CaAl}_{2} \mathrm{Si}_{2} \mathrm{O}_{8}$ & & 2.891E-04 & $7.456 \mathrm{E}-05$ & $\begin{array}{l}5.452 \mathrm{E}- \\
05\end{array}$ & 4.687E-04 \\
\hline Diopside & $\mathrm{CaMgSi}_{2} \mathrm{O}_{6}$ & & $6.261 \mathrm{E}-04$ & 1.181E-03 & \begin{tabular}{|l}
$1.079 E-$ \\
03
\end{tabular} & 8.809E-04 \\
\hline Kaersutite & $\mathrm{NaCa}_{2} \mathrm{Mg}_{4} \mathrm{TiSi}_{6} \mathrm{Al}_{2} \mathrm{O}_{23}(\mathrm{OH})$ & & & $2.927 \mathrm{E}-07$ & & \\
\hline Hauyne & $\mathrm{Na}_{3} \mathrm{CaSi}_{3} \mathrm{Al}_{3} \mathrm{O}_{12} \mathrm{SO}_{4}$ & & & $2.542 E-04$ & \begin{tabular}{|l}
$2.890 \mathrm{E}-$ \\
04
\end{tabular} & $9.094 \mathrm{E}-05$ \\
\hline Nepheline & $\mathrm{NaAlSiO}_{4}$ & & & & $\begin{array}{l}1.483 \mathrm{E}- \\
04\end{array}$ & $1.053 \mathrm{E}-03$ \\
\hline Phlogopite & $\mathrm{KMg}_{3} \mathrm{AlSi}_{3} \mathrm{O}_{10}(\mathrm{OH})_{2}$ & & & 2.073E-04 & $\begin{array}{l}2.951 \mathrm{E}- \\
04\end{array}$ & $6.265 \mathrm{E}-04$ \\
\hline Annite & $\mathrm{KFe}_{3} \mathrm{AlSi}_{3} \mathrm{O}_{10}(\mathrm{OH})_{2}$ & & & & \begin{tabular}{|l}
$2.987 E-$ \\
08
\end{tabular} & $2.987 E-08$ \\
\hline Forsterite & $\mathrm{Mg}_{2} \mathrm{SiO}_{4}$ & & 3.066E-04 & & & \\
\hline Fayalite & $\mathrm{Fe}_{2} \mathrm{SiO}_{4}$ & & 4.479E-08 & $4.480 \mathrm{E}-08$ & & \\
\hline Titanite & $\mathrm{CaTiSiO}_{5}$ & & 2.508E-07 & $2.927 \mathrm{E}-07$ & $\begin{array}{l}2.509 E- \\
07\end{array}$ & 2.300E-07 \\
\hline Fluorapatite & $\mathrm{Ca}_{5}\left(\mathrm{PO}_{4}\right)_{3} \mathrm{~F}$ & & 2.455E-06 & 4.535E-06 & $\begin{array}{l}1.756 \mathrm{E}- \\
06\end{array}$ & 2.844E-06 \\
\hline Fluorite & $\mathrm{CaF}_{2}$ & & 5.882E-06 & $3.791 \mathrm{E}-06$ & \begin{tabular}{|l|}
$5.972 E-$ \\
06
\end{tabular} & 4.901E-06 \\
\hline $\begin{array}{l}\text { Montmorillonite- } \\
\mathrm{Ca}^{3}\end{array}$ & $\mathrm{Ca}_{0.165} \mathrm{Mg}_{0.33} \mathrm{Al}_{1.67} \mathrm{Si}_{4} \mathrm{O}_{10}(\mathrm{OH})_{2}$ & \multirow{4}{*}{$\begin{array}{l}\text { Sink } \\
\text { phases }\end{array}$} & $-9.304 \mathrm{E}-04$ & & & $-9.723 \mathrm{E}-04$ \\
\hline $\begin{array}{l}\text { Montmorillonite- } \\
\mathrm{Mg}^{3}\end{array}$ & $\mathrm{Mg}_{0.495} \mathrm{Al}_{1.67} \mathrm{Si}_{4} \mathrm{O}_{10}(\mathrm{OH})_{2}$ & & $-8.844 \mathrm{E}-04$ & $-8.724 \mathrm{E}-04$ & $\begin{array}{l}-1.042 \mathrm{E}- \\
03\end{array}$ & $-7.291 \mathrm{E}-04$ \\
\hline $\begin{array}{l}\text { Montmorillonite- } \\
\mathrm{Na}^{3}\end{array}$ & $\mathrm{Na}_{0.33} \mathrm{Mg}_{0.33} \mathrm{Al}_{1.67} \mathrm{Si}_{4} \mathrm{O}_{10}(\mathrm{OH})_{2}$ & & $-1.175 \mathrm{E}-03$ & $-1.161 \mathrm{E}-03$ & $\begin{array}{l}-1.384 \mathrm{E}- \\
03\end{array}$ & $-9.700 \mathrm{E}-04$ \\
\hline $\begin{array}{l}\text { Montmorillonite- } \\
\mathrm{K}^{3}\end{array}$ & $\mathrm{~K}_{0.33} \mathrm{Mg}_{0.33} \mathrm{Al}_{1.67} \mathrm{Si}_{4} \mathrm{O}_{10}(\mathrm{OH})_{2}$ & & $-1.175 \mathrm{E}-03$ & & & $-1.244 E-03$ \\
\hline
\end{tabular}

Transfers of phases which occur in each of the found models, i.e. essential phases, are bolded; unbolded values refer to an optional phases which occur only in particular model(s). 1 - number of found models; 2 - composition of marine aerosols based on the mean sea water chemistry; 3 chemical formulas of montmorillonites used in the models are given accordingly to "llnl" thermodynamical database. 
Table 4. The weathering contribution (in \%) of silicate source mineral phases to the pool of silicon dissolved in studied groundwater. Mean values are given in brackets.

\begin{tabular}{|c|c|c|c|c|}
\hline \multirow{2}{*}{ Phase } & Post Roque Nublo & Roque Nublo & \multicolumn{2}{|l|}{ Phonolites } \\
\hline & Well 17 & Well 18 & Well 3 & Well 9 \\
\hline $\begin{array}{l}\text { Potassium } \\
\text { Feldspar }\end{array}$ & $7.469-26.370(12.981)$ & & & \\
\hline Albite & $\begin{array}{lll}39.658 & - & 58.552 \\
(48.565) & & \end{array}$ & \begin{tabular}{lll|}
22.876 & - & 37.272 \\
$(30.074)$ & &
\end{tabular} & $\begin{array}{lll}30.640 & - & 44.370 \\
(39.010) & & \end{array}$ & $\begin{array}{lll}36.233 & - & 60.613 \\
(49.139) & & \end{array}$ \\
\hline Anorthite & $9.875-11.341(10.328)$ & $1.988-3.182(2.587)$ & $1.536^{*}$ & $7.953-8.919(8.287)$ \\
\hline Diopside & $\begin{array}{lll}18.617 & - & 28.470 \\
(22.655) & & \\
\end{array}$ & \begin{tabular}{lll|}
37.227 & - & 47.724 \\
$(42.475)$ & &
\end{tabular} & \begin{tabular}{lll|}
29.327 & - & 38.750 \\
$(33.013)$ & &
\end{tabular} & $9.816-30.123(18.880)$ \\
\hline Kaersutite & & $0.028-0.035(0.032)$ & & \\
\hline Hauyne & & \begin{tabular}{lll|}
12.279 & - & 15.089 \\
$(13.685)$ & & \\
\end{tabular} & \begin{tabular}{lll|}
12.217 & - & 15.149 \\
$(13.241)$ & & \\
\end{tabular} & $2.288-3.360(2.811)$ \\
\hline Nepheline & & & $2.106^{*}$ & $\begin{array}{lll}11.710 & - & 13.670 \\
(12.387) & & \end{array}$ \\
\hline Phlogopite & & \begin{tabular}{lll|}
10.014 & - & 12.305 \\
$(11.160)$ & &
\end{tabular} & \begin{tabular}{lll|}
12.546 & - & 15.454 \\
$(13.516)$ & &
\end{tabular} & $\begin{array}{lll}16.611 & - & 20.980 \\
(18.830) & & \end{array}$ \\
\hline Annite & & & $0.001-0.002(0.001)$ & $0.001-0.001(0.001)$ \\
\hline Forsterite & $4.148-6.763(5.466)$ & & & \\
\hline Fayalite & $0.001-0.001(0.001)$ & $0.001-0.001(0.001)$ & & \\
\hline Titanite & $0.004-0.005(0.005)$ & $0.005-0.006(0.005)$ & $0.004-0.004(0.004)$ & $0.002-0.003(0.002)$ \\
\hline
\end{tabular}

Contributions of an essential phases are bolded; unbolded - an optional phases. ${ }^{*}$ - optional phase included only in the one found model 


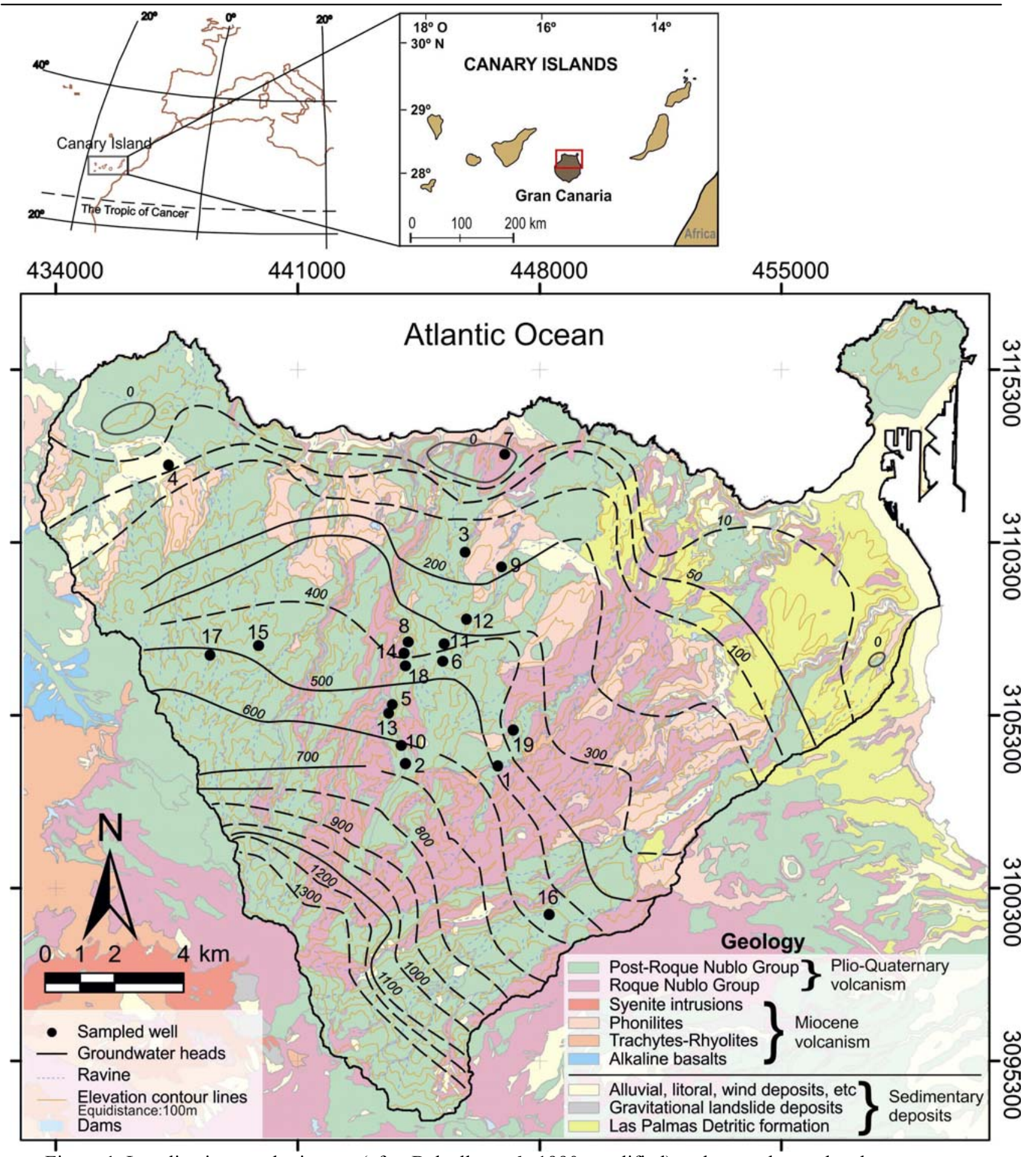

Figure 1. Localization, geologic map (after Balcells et al., 1990, modified) and groundwater head contours map (Benavides and Galindo, 2011) for 2008 of study area in the northern part of Gran Canaria. Explanations: 1-19 numbers of sampled water wells. 


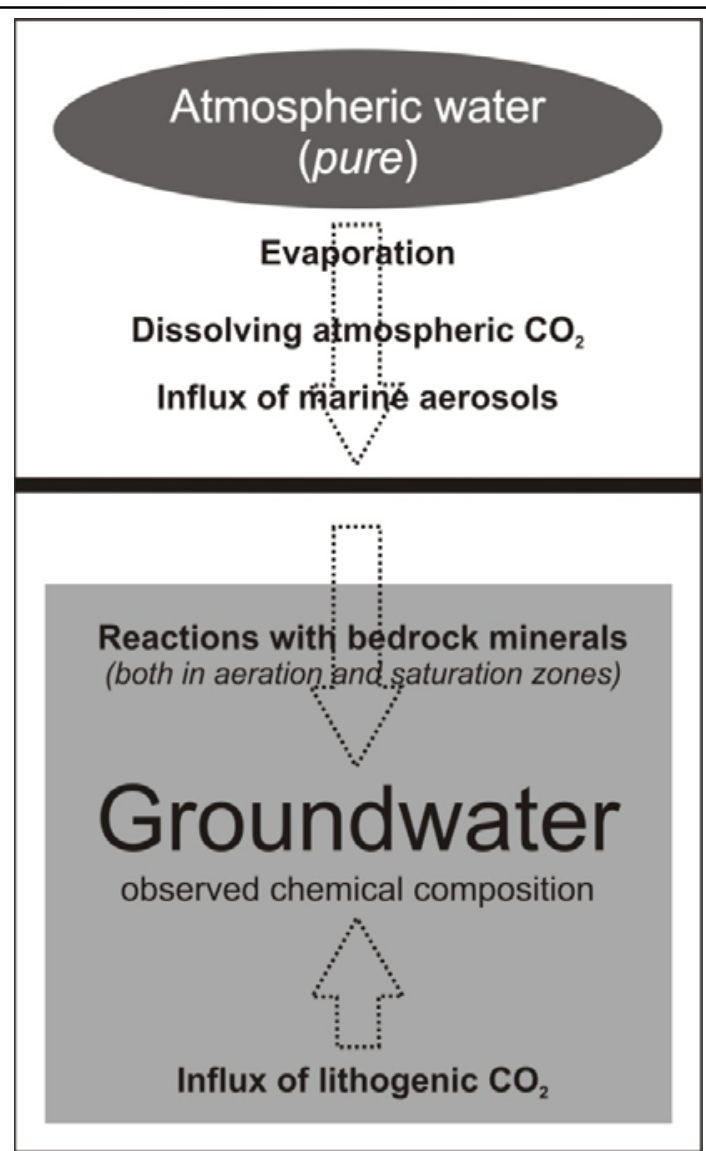

Figure 2. Scheme of conceptual geochemical model for water-rock interactions in Gran Canaria island.

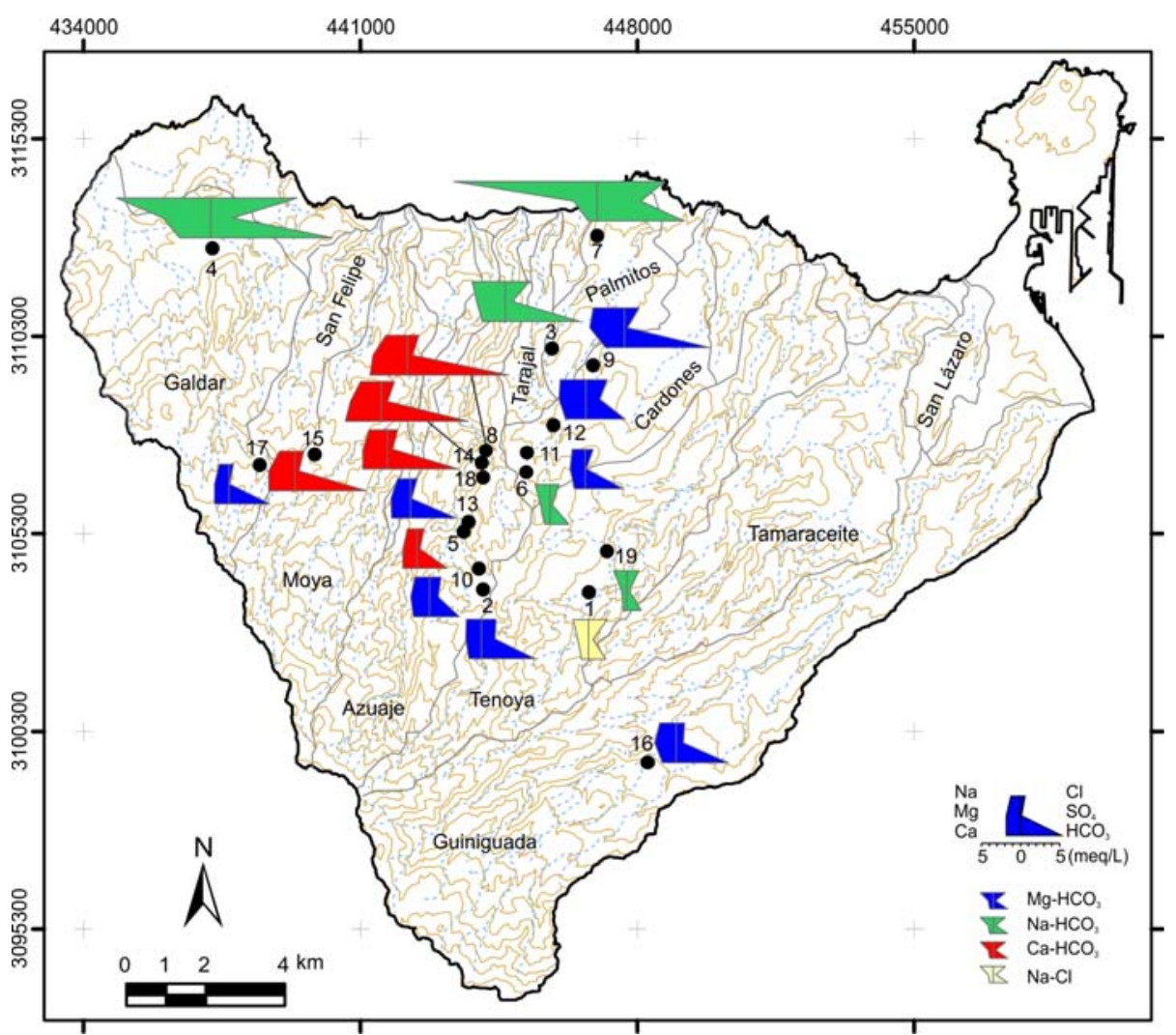

Figure 3. Stiff diagrams map reflecting groundwater chemistry of sampled wells. 


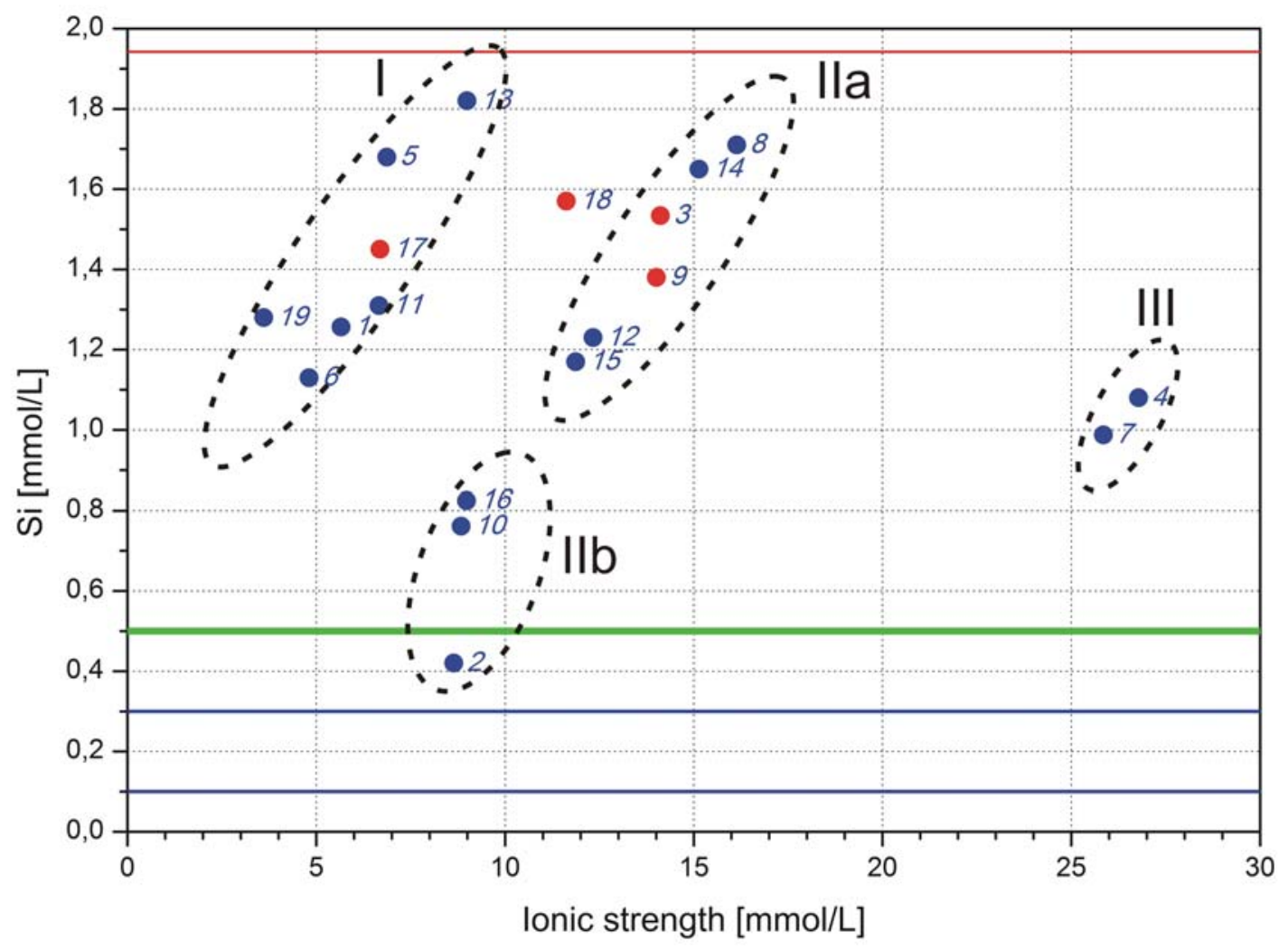

Figure 4. Silicon concentration versus ionic strength of groundwater. Explanations: 1-19 - numbers of sampled wells. Groups of wells: I - groundwater chemistry dominated by interactions with Post Roque Nublo and Roque Nublo volcanic rocks; IIa, IIb - groundwater chemistry dominated by interactions with Phonolites and Roque Nublo volcanic rocks; III - groundwater chemistry affected by irrigation and/or sea salinity. Green line - minimum threshold value of Si content $(0.5 \mathrm{mM})$ suggested as a beneficial for human health (after Exley et al., 2006); red line - solubility limit of silicic acid $(1.94 \mathrm{mM})$, at $25^{\circ} \mathrm{C}$; dark blue lines - ranges of silicon content typical for fresh groundwater. Groundwater used in inverse geochemical modelling (wells nos. 3, 9, 17, and 18) are marked as red filled circles. 


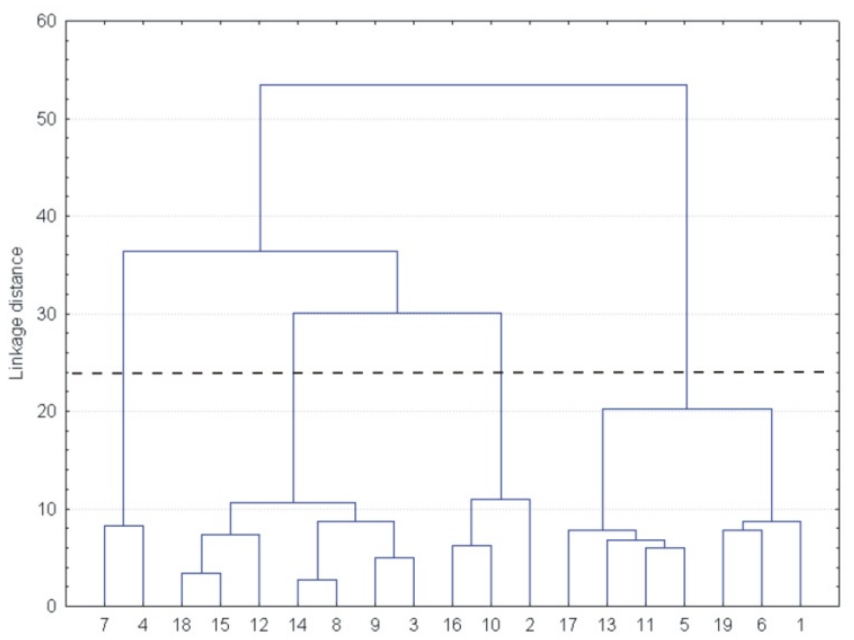

$5 \mathrm{~A}$

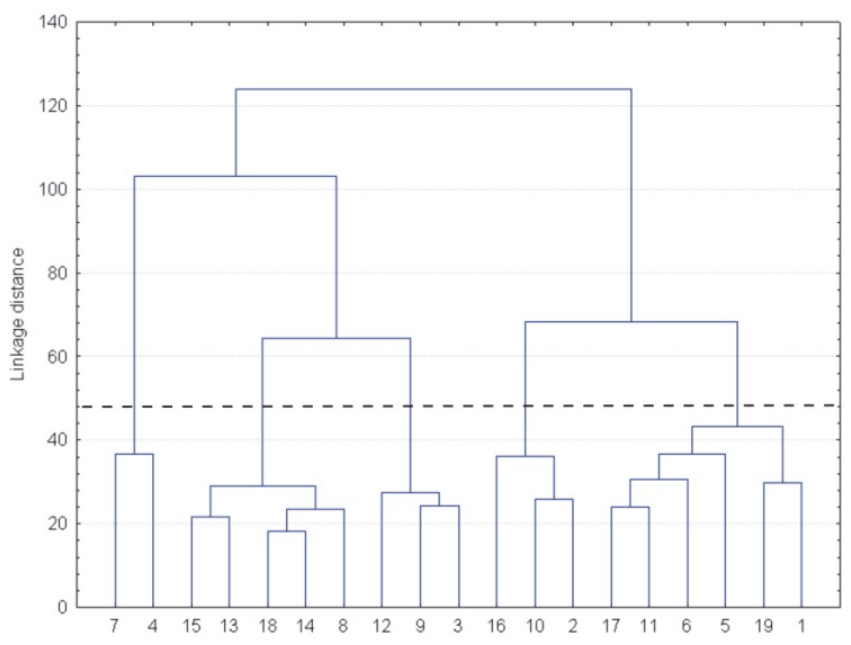

$5 \mathrm{~B}$

Figure 5. Hierarchical Q-mode cluster dendrograms of studied groundwater based on: 5A - major solutes chemistry data; 5B - major and minor chemistry data, water table data, and contribution of bedrocks in alimentation zone. 1-19 numbers of sampled wells. Dashed lines added for highlighting groups of clustered water members. 

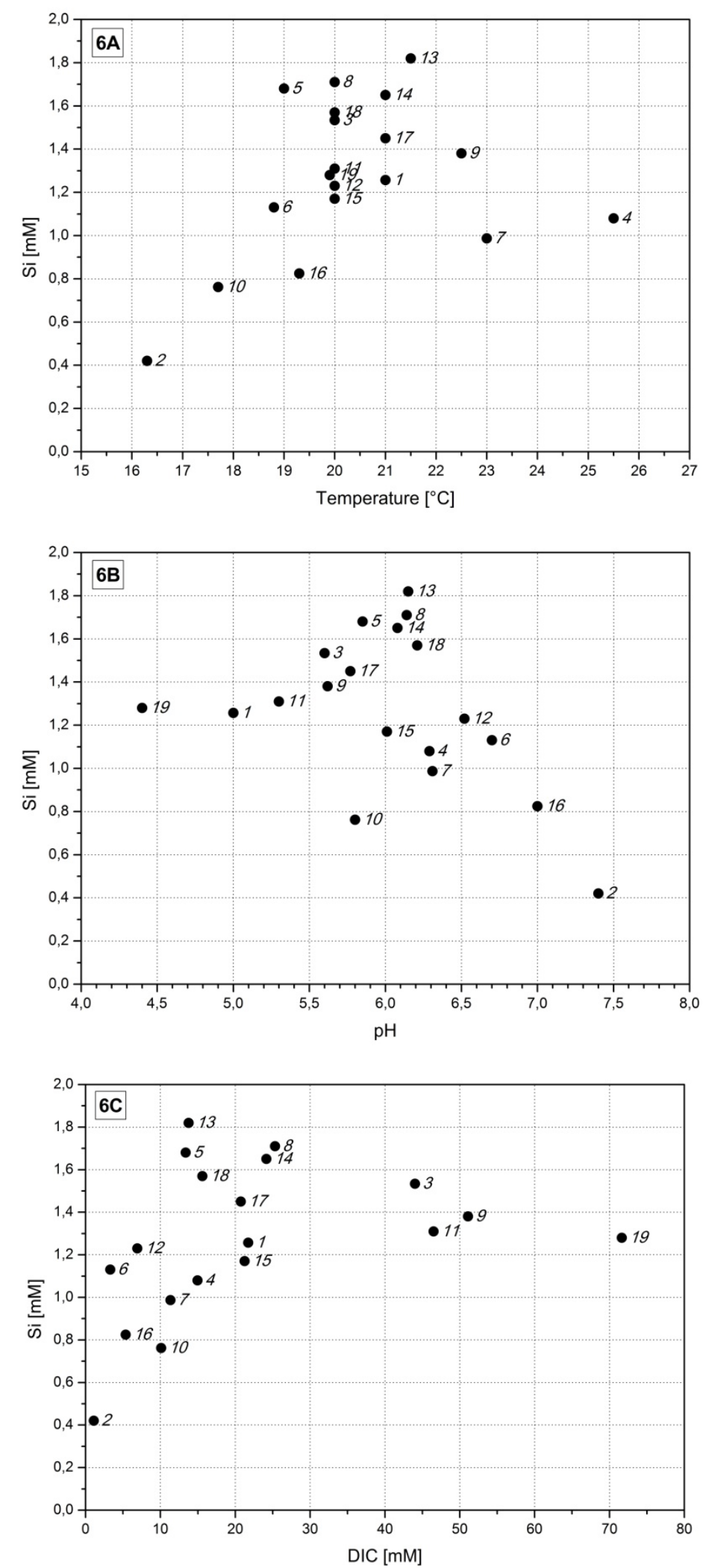

Figure 6. Silicon concentration versus temperature (6A), $\mathrm{pH}(6 \mathrm{~B})$, and dissolved inorganic carbon (6C) in groundwater. 1-19 - numbers of sampled wells. 